\title{
MANGROVE FOREST DESTRUCTION IN DAMAS BEACH, EAST JAVA, INDONESIA: SOCIO-ECOLOGICAL ANALYSIS
}

\author{
Susilo Edi ${ }^{*}$, Lestariadi Riski Agung, Fattah Mochammad \\ Faculty of Fisheries and Marine Sciences, University of Brawijaya, Indonesia \\ *E-mail: olisuside@gmail.com
}

\begin{abstract}
The high percentage of land conversion from mangrove forests to plantation for coconut and other crops between 1998 and 2013 resulted in sharp decline of mangrove forest in Damas Beach. Damas beach is one of the areas covered by mangrove forests in Teluk Prigi and located on the most western area. The total area of the mangrove forest in 1998 was 10 hectares. The number decreased to $30 \%$ in 2013. Even though reforestation had been taken place, the mangrove area keeps decreasing. It affected coastal resources, more particularly the number of catch. Fish is the backbone of the local communityliving around the mangrove forest. The purpose of the study was to give information, for both personal and institutional, that is likely to impact the dynamics of mangrove forest area in Damas Beach. In addition, it also describes the level of mangrove forest destruction more particularly as the effect of human activity. It is expected that soci-ecological system is taken into account in order to establish sustainable management program for mangrove forest.
\end{abstract}

\section{KEY WORDS}

Mangrove Forest Destruction, Function of Mangrove Forest, Coastal Resource Management, Socio-Ecological System, Damas Beach

Benda et al (2001) introduced the concept of natural resources as public social security in order to develop awareness among Indonesian that they have damage the environment that becomes their source of income. The expert mentioned the findings of various studies conducted in various regions in the country. Not only does the book enrich our understanding towards sufficient social security, but it also highlights the discrepancy in the national system of social security.

Study focusing on resources from mangrove forest was conducted by Susilo et al (2013); the findings stated that the political and economic system in Karanggandu heavily influenced the sustainability of mangrove resources. Mangrove forest conservation is instrumental to guarantee social security for local community. When mangrove forest turns into coconut plantation and rice field, the local community may lose their social security. Furthermore, economic system-based sustainable coastal management works besrt when it begins in the local area since operational-wise, local economic system heavily influences resource management system.

Mangrove forest area in Pancer Bang has decreased drammatically. In 2008, the Department of Marine and Fisheries of Trenggalek reported that the total area of mangrove was 12 hectares. Due to the rapid conversion from mangrove forests to coconut plantation and plantations for other crops, the total area of mangrove in Pancer Bang shrunk.

Some deforestation programs have been carried out by the Department of Marine and Fisheries of Trenggalek in Pancer Bang, for example planting approximately 95,000 mangrove seedlings (Nypa fruticans, Rhizophora mucronata and Rhizophora apiculata). Based on the observation in 2013 , it is evident that there is massive land conservation in Pancer Bang mangrove area (Figure 1).

Pancer Bang mangrove shrunk to $30 \%$ or approximately to 3.6 hectares. The largest land conversion happened in the tidal area around Damas and Gilang River. 2.8 hectares of mangrove around Damas River became plantation and residential area while another 2.8 hectares became coconut plantation. As an addition, 3.6 hectares of mangrove in the tidal area around Gilang River has been turned into coconut plantation. 


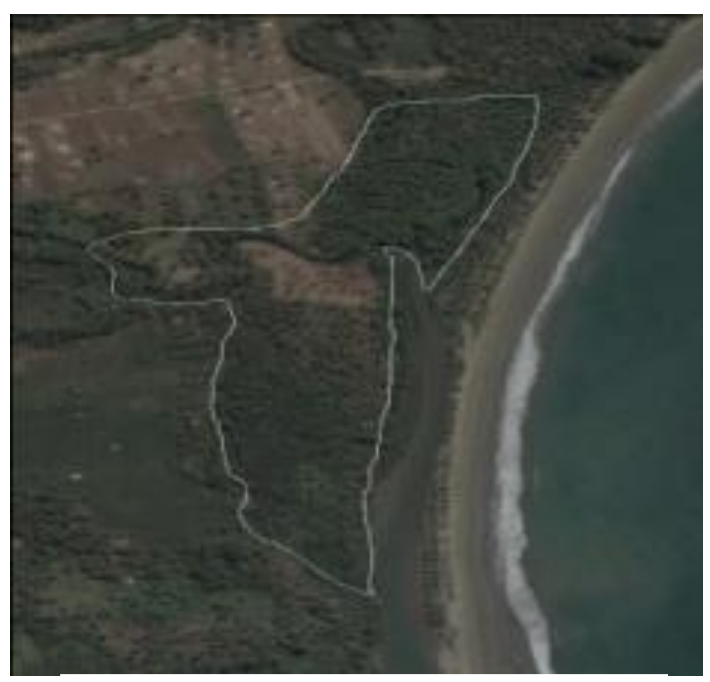

a. Mangrove Forest in 2008

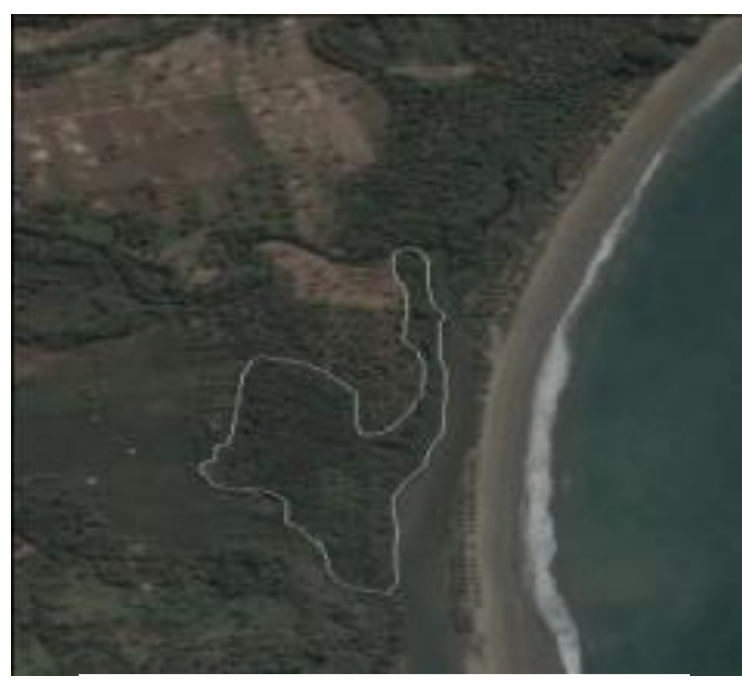

b. Mangrove Forest in 2013

Figure 1 - Land Conservation in Pancer Bang Mangrove Forest (Susilo, et al. 2013)

Observation in 2015 revealed two different facts. Pancer Bang mangrove area keeps declining; currently, there are only 3 hectares of mangrove in the area. Coastal erosion also becomes a threat to Pancer Bang mangrove since the rehabilitation area is now no longer protected from the tidal waves. In the other side, 500 mangrove trees are planted in Pancer and Ngrumpukan. Therefore, it is important to conduct a study focusing on the dynamics of the mangrove forest in the area more particularly from the social perspective.

\section{LITERATURE REVIEW}

Significance of Coastal Resource Social Security for Local Community. National-scale event has always had impact towards local community. The process is called sociological reflection. The establishment of the 1975 Rural Government Regulation affected indigenous resource management such as coastal resource management e.g. Sasi, Panglima Laot, and Awig-Awig.Natural resource as social security can no longer give maximum protection. Abdullah and Saleh (2001) described remaining issues in relation to resource and social security, namely (1) related to citizenship that means institutional and political recognition towards citizenship manifested in legislation system and government policy, (2) related to rights for possession of natural resources and public facilities which is related to authoritative issues, (3) social security issues related to access and control that guarantee the fulfillment of public rights towards available resources and (4) related to which groups being put in advantageous or disadvantageous position in various issues.

Related to management and utilization of coastal resources, the government has issued some regulations; however, they are not easy to apply. The regulations are Fisheries Act, Coastal Act, Natural Resource Conservation and Ecosystem Act as well as the Protection and Management of environment Acts. The government of Trenggalek has issued the 2004 Regional Regulation number 10 about Coastal resource Management. In 2008, another decree was issued by the Head of Marine and Fisheris Department of Trenggalek Decree or No: 188.45/842/406.060/2008 about Kelompok Masyarakat Pengawas/PokMasWas, a group of which responsibility was to provide supervision. One of the Pokmaswas is called Kejung Samudra located in Pancer Cengkrong, Karanggandu, Watulimo.

Significance of Mangrove for Human Being. The benefits and functions of mangrove forests are: (1) habitat for endangered species, (2) protection against natural disaster, (3) mud deposition, (4) nutrient replenishment, (5) prevent poison, (6) in-situ and ex-situ natural resources, (7) transportation, (8) germplasm, and (9) recreation and tourism, (10) means of education and research, (11) maintaining natural process and natural system, (12) carbon 
absorption, (13) maintaining microclimate, (14) and preventing development of acid sulphate soil.

Even though people are aware of how relevant mangrove is for human being, the area of mangrove in the national and international scale has reduced rapidly. Anwar (2010) in the national-scale within the last three decades the national mangrove forest has decreased from 4.25 million hectares to 3.7 million hectares. There was only 2.1 million hectares of mangrove that is in good condition. Internationally, there are 4.8 million hectares of severely damaged mangrove forest out of the total 5.5 million hectares of mangrove forest. The damage is caused by human or insufficient management. Preventive measure has been taken since the Fifth Five-Year Development and elevated in the Sixth Five-year Management until recently. Reforestation of mangrove forest in the coastal area had been conducted from 2003 to 2007. The reforestation was conducted to 70.185 hectares of the mangrove forest but unfortunately it has yet been successful. Numerous institutions and organizations understand how important mangrove forest is to protect coastal ecosystem. As the consequence, various efforts should be taken to protect mangrove forest.

Ecological History of Mangrove Forest. Based on the Cofish Project (2004), the total area of Pancer Bang mangrove forest is 32.27 hectares. The species of mangrove grown in Pancer Bang mangrove forest are varied in terms of size of seedlings, saplings, trunk and trees. There are 10 species of mangrove namely, Acanthus illicifolius, Lumnitzera racemosa, Nypa fruticans, Ceriop descandra, Soneratia Alba, Rhizopora mucronata, Aegiceras corniculatum, Rhizopora apiculata, Heritiera globosa dan Heritiera littoralis.

The three dominant species are Nypa fruticans, Rhizopora mucronatadan Soneratia Alba respectively. The mangrove ecosystmen in the coastal area of Karanggandu village consists of the following species, Aegiceras orniculatum, Ceriops tagal, Sonneratia $s p$, Rhizopphora spp, and Bruguiera (Department of Marine and Fisheries of Trenggalek, 2008). According to the locals, the species grown in the mangrove forest are kayu jaran, menengen, nipah, truntum, druju, layutan, bogem, jangkar and tapang. Based on the report of the Department of Marine and Fisheries of Trenggalek, the total area of mangrove forest in Pancer is 42.557 hectares; 32.5 hectares of the forest is in good condition but 10.057 hectares of the forest is severely damanged. The total area of mangrove forest in Pancer Ngrumpukan is 2,178 hectares; 2 hectares of the forest is in good condition whereas the remaining 0.178 hectares is in poor condition. The total area of mangrove forest in Pancer Bang is 6.022 hectares; 5 hectares of the forest is in a good condition and 1.022 hectares are severely damaged.

Susilo et al (2007) mentioned that mangrove forest reduced drastically; the potential area for mangrove forest is only 10 hectares and the total area of both natural and manmade mangrove forest is only 3.3 hectares. The total area of the natural mangrove forest is 2 hectares dominated by Till-Stilted Mangrove including 5 centimeter-thick Rhizophora Sp. Mangroves are found only around the upper edges of the estuary. The total area of manmade mangrove forest (reforestation) is 0.3 hectares.

There are 3.6 hectares of mangrove forest in Pancer Bang more particularly around Gilang River that became coconut plantation, plantation and residential area whereas, 4.8 areas hectares of mangrove forest around Damas River that is now coconut plantation, plantation and residential area. The mangrove forest around Gilang River is turned into coconut crop areas, while that around Damas River is now residential area, plantations and coconut plantation. The area can potentially be used to develop mudcrab and fishing industry. The remaining 2.8 hectares can be used as plantation and residential area (Susilo et al, 2013).

The ecological history of the mangrove forest in Prigi Bay can be described as follow (Purwanti, et al. 2015). There are only three areas of mangrove forest left. The mangrove forest in Pancer Cengkrong is well-maintained by Kejung Samudra, supervision group.It becomes ecotourism and edutourism locations as well as the major tourism destination for the local visitors. The government of Trenggalek gives legitimation to the management process. The opposite situation takes place in Damas Beach. The mangrove forest in Pancer Bang and Ngrumpukan is damaged due to natural phenomenon and conversion of the forest 
into coconut plantation and residence. In addition, local institution appointed to manage the area is "dormant». Pancer Bang and Ngrumpukan are relatively accessible to the local community so that they can make use of the areas easily.

The condition of the mahgrove forest in Damas Beach cannot be spearated from the mechanism of LMDH Argo Lestari, the organization appointed to manage the area, that tends to put Damas Beach in their management. Local politics and economic authority, where "Mbah Demang» is really influential in determining the future of the mangrove forest Damas Beach. Therefore, negotiation with the local public figure is one of the keys to the sustainability of institution responsible for managing the resources as well as sustainability of the mangrove forest resources. Coastal erosion also threatens the existence of Pancer Bang. LMDH Argo Lestari has dregged the sand covering the river twice. The waves erode the shoreline and the sand is back to the river.

Socio-Ecological Analysis in Coastal Resource Management. Socio-Ecological System (SES) is an ecological system that is closely related to/ and influenced by one or more social systems. Relationship between ecosystem and social system was first introduced by Rambo in the 1980s. Ecological system can be defined as an interdependent system from organism or biological unit. "Social» means «the tendency to establish cooperation and interdependence with others of the same kind».

Social-Ecological System is used to refer to a subset of social system in which there are several interdependent relationship between people that is mediated through interactions with biophysical and biological units of non-human (Anderies et al., 2004). A simple example is when the fishing activities alter the outcome of other fishing activities through the interaction of biophysical and non-human biological unit that provides dynamic, lively fish stock. Furthermore, we limit our attention to SES where cooperative aspect of the social system becomes the key, that is, where people deliberately invest resource in some kind of physical and institutional infrastructure to cope with variety of internal and external interference. When the social and ecological systems are related to each other, SES as a whole is a complex system involving several adaptive subsystems, as well as being embedded in a larger double system (Anderies et al., 2004).

\section{RESEARCH METHODOLOGY}

The study used qualitative approach where the term population was not used in the type of research; instead the term social situation was used (Sugiyono, 2014). Social situation consisted of three elements, setting, actor and activities. The social situation in the study was as follow: the setting was Damas Beach, the actor was institution that caused increasing or decreasing area of mangrove forest while the activities were land conversion, preventive measures, deforestation and reforestation of the mangrove forest in Pancer Bang.

The data were in the form of the local or stakeholder's responses towards the mangrove forest as well as its social, economic and ecological function. They involved their perceptions, motivations and behavior towards the mangrove forest. Based on ecological perspective, the researchers explained the damage happened to the forest, particularly coastal erosion that threatened the mangrove forests as reforestation had been carried out. The samples are some informants consisting of: (1) the Head of LMDH Argo Lestari, (2) the Department of Marine and Fisheries of Trenggalek, (3) PSDKP in Prigi Beach, (4) the prominent figure of Damas community, which once managed and made use of the coastal resource such as Jangkar Bahari group, (5) Pe-Nggopla who use palm leaves for to make roofs for their huts in the forest. Furthermore, descriptive analysis was conducted by describing the social history of certain event so that there is ecological and social reflection oin the destruction of the mangrove forests.

\section{FINDINGS AND DISCUSSION}

Potential Institution and Individual that Influence the Dynamics of the Mangrove Forest Area. Susilo et al (2007) reported that coastal resource sustainability relied on which 
institution responsible for managing the resources, especially in an area where the indigenous regulation was no longer used. The mangrove forest in Damas Beach was located in two areas, Pancer Bang and Pancer Cengkrong. The mangrove forest area was affected by institution and individual involved in the management. Some institutions and individuals that affected the dynamics of the mangrove forest area was as follow (Table 1):

Table 1 - Relationship between Institutions

\begin{tabular}{|c|c|c|c|c|c|c|c|c|}
\hline$n / n$ & Mangrove & $\begin{array}{c}\text { Kejung } \\
\text { Samudera } \\
\text { Supervision } \\
\text { Group } \\
\end{array}$ & $\begin{array}{c}\text { Jangkar } \\
\text { Bahari } \\
\text { Supervision } \\
\text { Group } \\
\end{array}$ & LMDH & Pemdes & FPIK & $\begin{array}{l}\text { Indonesian } \\
\text { State Forestry } \\
\text { Enterprise }\end{array}$ & DKP \\
\hline Mangrove & & ++ & ++ & -- & ++ & ++ & -+ & ++ \\
\hline $\begin{array}{c}\text { Kejung } \\
\text { Samudera } \\
\text { Supervision } \\
\text { Group }\end{array}$ & & & ++ & -+ & ++ & ++ & -- & ++ \\
\hline $\begin{array}{c}\text { Jangkar Bahari } \\
\text { Supervision } \\
\text { Group }\end{array}$ & & & & -+ & ++ & ++ & -- & ++ \\
\hline LMDH & & & & & ++ & ++ & ++ & -- \\
\hline $\begin{array}{c}\text { Local } \\
\text { Government }\end{array}$ & & & & & & ++ & ++ & ++ \\
\hline FPIK & & & & & & & ++ & ++ \\
\hline $\begin{array}{l}\text { Indonesian } \\
\text { State Forestry } \\
\text { Enterprise }\end{array}$ & & & & & & & & -- \\
\hline DKP & & & & & & & & \\
\hline
\end{tabular}

Notes: (++): positive, (--): negative, and (-+): neutral.

Based on the Head of the Department of Marine and Fisheries Decree of Trenggalek No.: 188.45/842/406.060/2008, the responsibilities of the Kejung Samudra were: (1) reporting any violation related to marine and fisheries, and (2) being in-site supervisors and controlling the coastal resources management and utilization. Even though Kejung Samudra headquarter was in Pancer Cengkrong, their responsibility involved Damas Beach.

Despite of the lack of facility and legality issue, Jangkar Bahari, supervision group kept managing the mangrove forest resources in Damas Beach. The group talked to the researchers thorugh the phone reporting the damage to the mangrove forest by the locals in 2011 and the conversion of the mangrove forest into fishpond.

LMDH Argo Lestari was responsible for 4.800 hectares of the forest including that in Damas Beach. $L M D H$ built some dams to as an effort to prevent coastal abrassion. The effort failed twice. On the other side, $L M D H$ turned the mangrove forest into coconut plantation in 2003 before the organization was established officially.

Team of researchers from the Faculty of Marine and Fisheries had etsablished a draft related to Mangrove and Coral Reef Management in 2007; however, the draft had yet been discussed among the local staffs. The draft had yet been discussed when the new head of village was elected in 2013 either. However, in 2015 together with the implementation of mangrove forest reforestation, the Head of Karanggandu village was comitted to support all programs of which purpose Damas Beach mangrove forest conservation.

Indonesian State Forestry Enterprise and dengan Kantor Resort Pemangku Hutan in Karanggandu did not have any program related to Damas Beach mangrove forest conservation. They work together with $L M D H$ Argo Lestari to run the operational activities and management of the forest.

The Department of Marine and Fisheris of Trenggalek paid full attention to the mangrove forest in Damas Beach starting from the Cofish project that lasted between 1998/1999 and 2005. Conservation program and establishment of supervision groups in Damas Beach were the efforts of the institution. Unfortunately, the institution has decided to pay more attention to the Pancer Cengkrong mangrove forest since 2008. The researchers 
from the Faculty of Marine and Fisheries conducted some studies and commonity service. The study was related to zoning, and strengthening the institutions responsible for coastal resource management. Studies related to the institutional management of coastal resources and food security were conducted in 2007 (Susilo, et al, 2007). A study related to institutional and household economic issues was conducted in 2013 (Susilo, et al, 2013) and in 2015, community service of which purpose was raising awareness about the significance of the mangrove forest for human being and planting 500 mangrove trees were conducted (Purwanti, et al, 2015).

The farmers contributed to the damage of the mangrove forest because they turned the forest into plantation or ricefield. Nobody stopped these activities and as the effect, the mangrove forest area kept decreasing. The penggopla cut down the palm trees for making the roof for their huts in the forest included in gopla area.

Socio-Ecological System of the Mangrove Forest in Damas Beach. Mangrove forest had both direct and indirect advantage for the society. Damas mangrove forest had 10 species of mangrove and among the ten species, there were three dominant species. The management of the mangrove forest officially begun when the forest became the setting for the Cofish Project (1998/1999 to 2005). Susilo et al (2007) described that the ecologicy in 1975 was immaculate, but some damage happened between 1975 and 1990. Furthermore, Susilo et al (2013) revealed that the locals damaged the forest starting from 1999 to 2001. The wood from the mangrove forest was used for building houses and fuel (charcoal). Bogem, one type of mangrove species, was cut and used as bottle cap. 0.5 hectares of Pancer Bang mangrove forest, the half of the total forest area, was turned into rice-field in 2005. Another half was turned into coconut plantation. Some reports related to the violation had been delivered to the Department of Marine and Fisheries. These activities were categorized as "error" in the ecological behavior of the locals. Their economic behavior sacrificed the function and ecological significance of the mangrove forest which eventually costed the local society.

Table 2 - Analysis of the Socio-Ecological System in the Destruction of the Mangrove Forest

\begin{tabular}{|c|c|c|c|}
\hline Variable & Input & Process & Output \\
\hline \multirow[t]{2}{*}{ Ecosystem } & $\begin{array}{l}\text { Mangrove: } \\
\text { 1. } \text { Acanthus illicifolius, } \\
\text { 2. Lumnitzera racemosa, } \\
\text { 3. } \text { Ceriop descandra, } \\
\text { 4. Nypa fruticans, } \\
\text { 5. Soneratia Alba, } \\
\text { 6. Aegiceras corniculatum, } \\
\text { 7. Rhizopora mucronata, } \\
\text { 8. Rhizopora apiculata, } \\
\text { 9. Heritiera littoralis. } \\
\text { 10. } \\
\text { Heritiera globosa dan }\end{array}$ & $\begin{array}{l}\text { In } 1975 \text {, the ecology was in a } \\
\text { good condition and between } \\
1975 \text { and } 1990 \text { there was some } \\
\text { damage to the mangrove forest } \\
\text { (Susilo et al, 2006). }\end{array}$ & $\begin{array}{l}\text { Species: Dominant: } \\
\text { 1. Nypa fruticans, } \\
\text { 2. Rhizopora } \\
\text { mucronatadan } \\
\text { 3. Soneratia Alba }\end{array}$ \\
\hline & Coconut Tree & $\begin{array}{l}\text { Planting coconut tree through } \\
\text { the land conversion }\end{array}$ & $\begin{array}{l}\text { Coconut was the dominant } \\
\text { species in Damas Beach }\end{array}$ \\
\hline \multicolumn{4}{|c|}{ Ecological System of the Mangrove Forest } \\
\hline \multirow[t]{4}{*}{$\begin{array}{l}\text { Reforestation of } \\
\text { the Mangrove } \\
\text { Forest }\end{array}$} & Cofish Project & $\begin{array}{l}\text { One of them was to protect the } \\
\text { mangrove forest in Damas } \\
\text { Beach (Pancer Bang and } \\
\text { Ngrumpukan) }\end{array}$ & $\begin{array}{l}\text { Establish the Supervision } \\
\text { Group (Mangrove Forest } \\
\text { Supervision Group) }\end{array}$ \\
\hline & \multirow[t]{3}{*}{ Planting Mangrove Seedling } & Cofish project & \\
\hline & & JNT & $\begin{array}{l}1,000 \text { mangrove seedlings } \\
\text { were damaged due to the } \\
\text { land conversion }\end{array}$ \\
\hline & & FPIK UB (2015) & $\begin{array}{l}\text { The area of mangrove } \\
\text { forest in Pancer Bang } \\
\text { increased }\end{array}$ \\
\hline Advantage & Long-Lasting & $\begin{array}{l}\text { Direct and Indirect Benefit and } \\
\text { Function of the Mangrove Forest }\end{array}$ & $\begin{array}{ll}\text { 1. } & \text { Crab, shrimp, clam } \\
\text { and other organisms } \\
\text { 2. Prevent abrasion } \\
\text { 3. Prevent sea water } \\
\text { intrusion }\end{array}$ \\
\hline
\end{tabular}


RJOAS, 1(61), January 2017

\begin{tabular}{|c|c|c|c|}
\hline Variable & Input & Process & Output \\
\hline \multirow[t]{2}{*}{ Solution } & $\begin{array}{l}\text { Draft Kesepakatan Lokal } \\
(D K L), \text { local agreement draft }\end{array}$ & $\begin{array}{l}\text { Discussion and approval of } D K L \\
\text { have yet been implemented }\end{array}$ & Violation \\
\hline & Facility & $\begin{array}{l}\text { The government and the society } \\
\text { in general supported on the } \\
\text { ecological sustainability using } \\
\text { social approach }\end{array}$ & $\begin{array}{l}\text { Social, Economic and } \\
\text { Ecological Sustainability }\end{array}$ \\
\hline Loss & Damage & $\begin{array}{l}\text { Economic issue and the lacking } \\
\text { knowledge of the society } \\
\text { resulted in irresponsible } \\
\text { utilization of the mangrove forest }\end{array}$ & $\begin{array}{ll}\text { 1. } & \text { Abrassion } \\
\text { 2. } & \text { Sea water intrussion }\end{array}$ \\
\hline \multirow[t]{3}{*}{$\begin{array}{l}\text { Destruction of } \\
\text { the Mangrove } \\
\text { Forest }\end{array}$} & \multirow[t]{3}{*}{ «Gopla» System } & $\begin{array}{l}\text { Conversion of the mangrove } \\
\text { forest: } \\
\text { 1. Pancer Bang mangrove } \\
\text { forest is now } 3.6 \text { hectares. It } \\
\text { was previously } 12 \text { hectares } \\
\text { 2. The violation had been } \\
\text { reported to the Department } \\
\text { of Marines and Fisheries }\end{array}$ & Planting coconut tree \\
\hline & & $\begin{array}{l}\text { The society raided the forest } \\
\text { between } 1999 \text { and } 2001\end{array}$ & $\begin{array}{l}\text { Mangrove Timber for: } \\
\text { 1. Building house } \\
\text { 2. Fuel (charcoal). } \\
\text { 3. } \text { Bottle cap (bogem) }\end{array}$ \\
\hline & & $\begin{array}{l}\text { In 2005, } 0.5 \text { hecatres, a half of } \\
\text { Pancer Bang }\end{array}$ & $\begin{array}{l}\text { KRD planted rice and corn } \\
\text { in the ricefield }\end{array}$ \\
\hline \multicolumn{4}{|c|}{ Social System of the Mangrove Forest } \\
\hline Institution & $L M D H$ & $\begin{array}{l}\text { Established on July } 18,2005 \text { as } \\
\text { the official forum for Hutan } \\
\text { Pangkuan Desa Karanggandu } \\
\text { community in order to optimize } \\
\text { the ecological and economic } \\
\text { functions of forests. }\end{array}$ & $\begin{array}{l}\text { Plants included in the } \\
\text { agreement which is } \\
\text { prohibited by Indonesian } \\
\text { State Forestry Enterprise } \\
\text { to cut are felled coconut, } \\
\text { ketapang, mahogany, } \\
\text { durian, heron, cloves, } \\
\text { jengkol, teak, pine. }\end{array}$ \\
\hline \multirow[t]{3}{*}{ Institution } & Department of Forestry & $\begin{array}{l}\text { Cooperation between the } \\
\text { Indonesian State Forestry } \\
\text { Enterprise and } L M D H\end{array}$ & $\begin{array}{l}\text { Legalized the land } \\
\text { conversion of the } \\
\text { mangrove forests }\end{array}$ \\
\hline & $\begin{array}{l}\text { Department of Marine and } \\
\text { Fisheries }\end{array}$ & $\begin{array}{l}\text { Indonesian State Forestry } \\
\text { Enterprise had the rights to } \\
\text { manage the mangrove forest so } \\
\text { that } D K P \text { could not have any } \\
\text { contribution in the management } \\
\text { of the forest }\end{array}$ & $\begin{array}{l}\text { Carrying out its } \\
\text { responsibility }\end{array}$ \\
\hline & $\begin{array}{l}\text { Department of Tourism, } \\
\text { Sport and Youth }\end{array}$ & $\begin{array}{l}\text { Tourist activities in Damas } \\
\text { Beach }\end{array}$ & Number of visitors \\
\hline \multirow[t]{4}{*}{ Society } & Gopla & $\begin{array}{l}\text { Public activities that generate } \\
\text { income }\end{array}$ & $\begin{array}{l}\text { Planting productive plants } \\
\text { in the public forest }\end{array}$ \\
\hline & $L M D$ & $\begin{array}{l}\text { The local politician affiliated with } \\
\text { Golkar, PPP, or PDI depend on } \\
\text { the local political atmosphere }\end{array}$ & $\begin{array}{l}\text { Currently affiliatd with the } \\
\text { local public figure and he } \\
\text { also help collecting the } \\
\text { data }\end{array}$ \\
\hline & Mangrove forest utilization & $\begin{array}{l}\text { The mangrove forest produced } \\
\text { economic commodity so that the } \\
\text { society could make use of the } \\
\text { commodity }\end{array}$ & $\begin{array}{l}\text { Economic commodity from } \\
\text { the mangrove forest such } \\
\text { as crabs, clams and shrimp }\end{array}$ \\
\hline & Management & $\begin{array}{l}\text { Management has yet been } \\
\text { sufficient }\end{array}$ & Non-optimum management \\
\hline
\end{tabular}

The locals thought that they could not generate money from the mangrove forest because the forest did not produce economic commodities such as raw materials for making broomsticks, young coconut leaves or coconut. Indonesian State Forestry Enterprise etsablished Lembaga Masyarakat Desa Hutan (LMDH) in 2005 that prohibited people from cutting down certain plants sucgh as coconut, ketapang, mahogany, durian, pucung, clove, jengkol, teak and pine. It increased the number of coconut trees. Head of $L M D H /$ former 
head of the village (LMD) owned the largest coconut plantation and as the effect, more people grew coconut trees and destroyed the mangrove.

The conservation project began with Cofish project where supervision group responsible for managing the mangrove forest in Damas Beach was established. 1,000 mangrove seedlings were destroyed due to human activities. A lot of researchers attempted to conduct conservation project in the area. In 2013, the negatiation to achieve ecological sustainability proposed a draft about the mangrove resort management. Susilo, et.al (2007) initiated the draft but unfortunately the local government of Karanggandu village had yet given any positive response. In 2015, a team from the Faculty of Marine and Fisheries of Brawijaya University conducted training to raise the locals awareness towards instrumental role of the mangrove forest for their lives. Besides that, the team planted 500 mangrove seedlings.

Table 2 described the analysis of the socio-ecological system in the destruction of the mangrove forest.

It was concluded that the simultaneous interaction between the social and ecological aspects influenced the total area of the mangrove forest in Damas Beach, both in Pancer Bang and Ngrumpukan. Nevertheless, it was expected that awareness and personal approach to the public figures may revitalize the mangrove forest. $L M D H$ was responsible for 4.800 hectares of the forest, and therefore, there was high possibility to revitalize the mangrove forest as it used to (10 hectares) or at least, the land conversion in the area did not worsen since the total area of the mangrove forest was recently only 5 hectares.

\section{CONCLUSION}

The conclusions are (1) certain institution and individual that are able to influence the dynamics of mangrove forest area can be divided into three categories. The first was the institution that maintain and carry out mangrove forest conservation program such as Kejung Samudra, Jangkar Bahari, the Department of Marine and Fisheries, and the Faculty of Marine and Fisheries, Brawijaya University. Second, neutral institution that preserve and restore habitats in the for example, the local government of Karanggandu village and the Indonesian State Forestry Enterprise. Third, institution and individual that most likely become threats to Damas mangrove forest preservation, namely $L M D H$ Argo Lestari, the coconut farmers and penggopla. (2) The interaction between social and ecological aspects simultaneously affects the dynamics of the mangrove forest in Damas Beach. However, it is expected that awareness and personal approach to the public figures facilitates the restoration of the mangrove forest. $L M D H$ is responsible for 4.800 hectares of the forest, so there is high possibility to restore the forest to what it was then (10 hectares) or at least more damage does not happen to the remaining 5 hectares of the mangrove forest.

Based on the conclusion, some efforts should be taken for the conservation of the mangrove forest area, namely (1) build dams to reduce coastal erosion caused by the waves, (2) negotiate with the local public figures hoping that they are willing to support the conservation of the mangrove forest, (3) developing awareness about the importance of the coastal ecology through local content subject as early as possible to the students of the elementary schools located in Karanggandu village, (4) encourage Kejung Samudra and the Faculty of Marine Science and Fisheries, Brawijaya University to periodically conduct mangrove reforestation, both in Pancer Bang and Pancer Ngrumpukan. (5) encourage the local government of Karanggand village to discussi the draft for Damas mangrove and coral reef management.

\section{REFERENCES}

1. Abdullah, I., and Saleh, A.A. (2001). Sebuah Pengantar: Pentingnya Jaminan Sosial dalam Masyarakat yang Sedang Berubah. Pustaka Pelajar, Yogyakarta.

2. Anderies, J.M., Janssen, M.A., and Ostrom, E. (2004). A framework to analyze the robustness of socialecological systems from an institutional perspective. Ecology and Society 9(1), 18. http://www.ecologyandsociety.org/vol9/iss1/art18 
3. Anwar, C. (2010). Rencana Penelitian Integratif «Pengelolaan Hutan Mangrove». Jakarta.

4. Benda, B.F., Keebet V.B.B., and Koning, J. (2001). Jaminan Sosial Dan Manajemen Sumberdaya Alam: Refleksi Kompleksitas Normatif di Indonesia. Pustaka Pelajar, Yogyakarta. pp. 1- 20.

5. Cofish Project. (2003). Reaching for The Future. Planeta Komunikatama, Jakarta.

6. Purwanti, P., Susilo, E., and Lestariadi, R.A. (2015). Pengembangan Model Pengelolaan Agroforestry Mangrove Di Kabupaten Trenggalek; Pendekatan Kelembagaan Dan Ekonomi Rumah Tangga (Laporan Kemajuan). LPPM-UB, Malang.

7. Sugiyono. (2014). Metode Penelitian Kuantitatif, Kualitatif dan R\&D. Alfabeta, Bandung.

8. Susilo, E., Hidayat, K., Syafa'at, R., Musa, M., and Purwanti, P. (2008). Daya Adaptasi dan Jaminan Sosial Masyarakat dalam Rangka Mencapai Ketahanan Pangan Domestik (Dinamika Kelembagaan Lokal Pengelola Sumberdaya Perikanan Kawasan Pesisir) Laporan Penelitian IRD. Kementerian Negara Riset dan Teknologi Republik Indonesia.

9. Susilo, E., Purwanti, P., and Indrayani, E. (2013). Kajian Pengembangan Pengelolaan Agroforestry Mangrove Melalui Penguatan Ekonomi Rumahtangga dan Kelembagaan Pengelolaannya di Kawasan Teluk Prigi Kabupaten Trenggalek. LPPM Universitas Brawijaya Malang, Malang. 